\title{
Prediction of Sediment Yield in Runoff from Agricultural Land in the Southern Guinea Savanna Zone of Nigeria
}

\author{
N. A. Egharevba* and H. Ibrahim \\ Department of Agricultural Engineering, Federal University of Technology, Minna, Niger State, \\ Nigeria \\ *Corresponding author; E-mail: naegharevba@yahoo.com
}

\begin{abstract}
Records on 111 natural rainfall events covering 2 years (2001 and 2003) were used to estimate the sediment yield in runoff from a bare surface Alfisol, and a similar soil under straw mulch and natural grass in the southern Guinea savanna zone of Nigeria. Measurements of runoff amount and sediment load were made for the months of MaySeptember of each year. The mean monthly runoff amount for the straw mulch, grass and the bare plots were $21.5 \mathrm{~mm}$, $50.3 \mathrm{~mm}$ and $64.1 \mathrm{~mm}$, respectively. The mean sediment load from the straw mulch and grass plots were $0.23 \mathrm{t} / \mathrm{ha}$ and $0.5 \mathrm{t} / \mathrm{ha}$, respectively. The corresponding monthly mean sediment yield of $1.64 \mathrm{t} /$ ha from the bare plot was 2.8 and 7.5 times greater than the grass and straw mulch plot, respectively, indicating the effectiveness of the latter in reducing splash erosion. The sediment yield was regressed on the runoff depth and the rainfall amount to obtain linear relation that can be used to predict sediment yield on Alfisols under bare farm land environment.
\end{abstract}

\section{Introduction}

Sediment yield, usually expressed as tonnes per unit area of the basin per year, is the amount of sediment measured at the runoff exist point in the basin area. It is always less than the total erosion due to sediment storage during transport and is highly variable because of measurement difficulty, the temporal variability of hydrological processes, and changes in land management practices in the basin from one year to the next.

Eroded sediment can carry nutrient particularly phosphates to water-ways and contribute to eutrophication of lakes and streams. Absorbed pesticides are also carried with eroded sediments, adversely affecting surface water quality (FAO, 1996; Webster \& Wilson, 1980). The cost to the farmer is two-fold loss of productivity due to loss of natural nutrition and economic cost of fertilizer, which is added in the attempt to compensate for this loss.

For soil erosion to be controlled, tools are needed to estimate erosion that might occur at a location and land management to be used to control soil loss where necessary. Since it is very often impractical or impossible to directly measure soil loss on every piece of land, the tools used are usually mathematical equation and/or computer simulation model (Laflen et al., 2004). To estimate sediment yield, there are generally categories of procedures to consider: (1) predictive equation, (2) gross erosion and sediment delivery ratio computations, and (3) suspended sediment load or reservoir sediment deposition measurements.

The revised universal soil loss equation (RUSLE) is a tool to estimate the rate of soil loss based on site-specific environ-ment condition and a guide for the selection and design of sediment and erosion control system for a site (Soil and Water Conservation Society, 1993). However, the RUSLE does not determine when soil erosion is excessive at a site or when erosion control systems have failed.

Estimation of sediment yield has important economic consequences. In many developing countries, the database with which to estimate reservoir life for example is very limited. According to White (1988), examples of predicted sediment yield in Asia tended to be between 2-16 times lower than actual measured rates, with the consequence that actual reservoir life was considerably reduced. This arises partly from the use of unreliable prediction techniques and the use of very short-term data, which usually fail to account for occasional but severe episodes of erosion (major storm events for example) and from increased land pressure after construction of reservoir. 
Regression equations relating the sediment yield and runoff depth for zero tillage with straw mulch as well as disc tillage with and without mulch under natural rainfall events in the moist Guinea savanna zone of Nigeria carried out by Egharevba (2004) were linear. More research will, however, be required under the southern Guinea savanna environ-ment (which stretches from Nigeria to some other West African countries) so as to come out with an exceptional wellvalidated and documented predictive equation.

The study was conducted with the following objectives: (1) Determination of rainfall-runoff relation, and (2) Generation of modelling equation for sediment yield for farm plots under bare surface condition.

\section{Site description}

\section{Material and methods}

The study area, Minna (Nigeria), lies between latitude $9^{\circ} 40^{\prime} \mathrm{N}$ and longitude $6^{\circ} 33^{\prime} \mathrm{E}$ of the Equator at elevation of about $400 \mathrm{~m}$ above sea level. Minna falls within the southern Guinea savanna vegetation zone with a sub-humid climate (Kaey, 1959; Onochie, 1977; Sanford \& Isicheri, 1980). The major rainy season occurs between June and October with its peak occurring in August. The mean annual rainfall is $1219 \mathrm{~mm}$ (Alabi \& Ibiyemi, 2000). The texture of the soil profile is an Alfisol and varied from sandy loam in the upper horizons to sandy clay in the deeper horizons with very low cation exchange capacity. The AP horizon $(0-23 \mathrm{~cm})$ exhibited dark yellowish brown colour, sandy loam texture, weak medium subangular blocky structure, very friable, many fine pores, many fine roots, and clear wavy boundary (Odofin et al., 2001).

The geology/parents material was of complex basement while the topography of the area is nearly level $(2 \%)$. The unsaturated hydraulic conductivity is in the range of $7.2-12.0 \mathrm{~cm} / \mathrm{d}$. The vegeta-tion covering the research project site were weedy species. Urena lobata (urena), Sida acuta (brown weed), and Indigogera lisuta (rough hairy indigo) were dominant weedy species. In addition, Panicum maximum (Guinea grass) was the dominant grass species. The bare plot was cleared of weed (weed litter and rock fragments greater than $5 \mathrm{~mm}$ were manually removed).

\section{Design of experiment}

The experimental layout was a complete block design for 2 years. In 2001, two treat-ments, namely the rice straw mulch surface, spread evenly at the rate of $0.5 \mathrm{~kg} / \mathrm{m}^{2}$ and bare surface were under investigation. In 2003, two treatments, namely bare surface condition and natural grass covered surface condition were evaluated. The grass and straw mulch plots were intended to determine the effect of vegetation on erosion. In 2002, only rainfall amount and runoff records were taken without the corresponding soil loss due to logistic problem. The data and data analysis for 2002 is, therefore, not reported here. The dimension of each runoff plot was $2.5 \mathrm{~m} \times$ $2.0 \mathrm{~m}$.

The runoff test plots size was to allow for effective collection of excessive runoff at peak period especially on bare plots. Each runoff plot was clearly demarcated with asbestos inserted $20 \mathrm{~cm}$ below the ground surface. A small channel boarding the lower side of each test plot collected runoff water and sediment load and discharged them via a plastic pipe into a collection tank installed in a pit (Fig.1). The runoff water in the collection tank was separated after settlement of the sediment had occurred. The MATHCAD 2000 Professional and statigraph software was used for the statistical analysis of the data under matrix plan of a $2^{2}$ factorial model. 


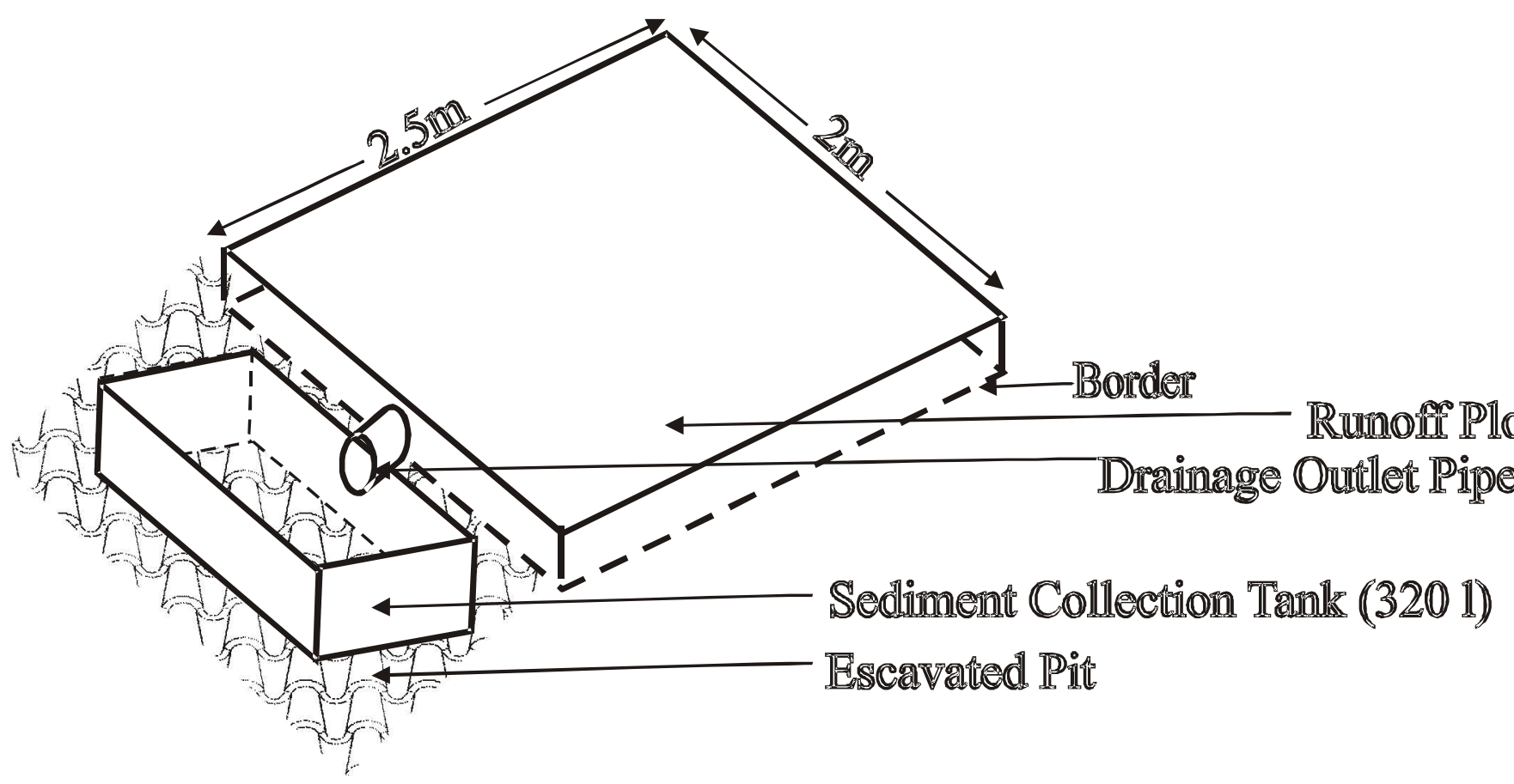

\section{Fig 1. Runoifi and Sediment Load Collection System}

Soil physico-chemical properties

\section{Results and discussion}

The texture of the soil profile varied from sandy loam in upper horizons to sandy clay in deeper horizons (Table 1). Increase in clay content with soil depth satisfied the criterion for classifying the profile as argillic. Since the BA horizon $(23-29 \mathrm{~cm})$ with $16 \%$ clay contained over 1.2 times as much clay as Ap horizon (0-23 cm) with 12\% clay (Soil Survey Staff, 1990). The profile exhibited mottled and plinthic subsoil characteristics. The soil revealed that it possessed poor physical and nutritional properties and, therefore, required good management to keep the soil loss within tolerance limit.

TABLE 1

Soil profile physico-chemical properties of experimental site

$20 \mathrm{~cm}$ soil depth intervals

Natural soil horizons

\begin{tabular}{|c|c|c|c|c|c|c|c|c|c|c|}
\hline Soil properties & $0-20$ & $20-40$ & $40-60$ & $60-80$ & $80-100$ & $0-23$ & $23-39$ & $39-64$ & $64-85$ & \\
\hline $85-111$ & $111-146$ & $146+$ & & & & (Ap) & $(B A)$ & $\left(B Z_{l}\right)$ & $\left(B Z_{2}\right)$ & \\
\hline$\left(B Z_{3}\right)$ & $\left(B Z_{v i}\right)$ & $\left(B Z_{v 2}\right)$ & & & & & & & & \\
\hline \multirow[t]{2}{*}{ Sand (\%) } & 76 & 70 & 66 & 60 & 52 & 74 & 68 & 62 & 56 & 48 \\
\hline & 56 & 56 & & & & & & & & \\
\hline \multirow[t]{2}{*}{ Silt (\%) } & 14 & 14 & 14 & 14 & 16 & 14 & 16 & 12 & 16 & 16 \\
\hline & 10 & 8 & & & & & & & & \\
\hline \multirow[t]{2}{*}{ Clay (\%) } & 10 & 16 & 20 & 26 & 32 & 12 & 16 & 26 & 28 & 36 \\
\hline & 34 & 36 & & & & & & & & \\
\hline \multirow[t]{2}{*}{ Textural class } & SL & SL & SL & SCL & $\mathrm{SC}$ & SL & SL & SCL & SCL & $\mathrm{SC}$ \\
\hline & SCL & $\mathrm{SC}$ & & & & & & & & \\
\hline Bulk density & 1.52 & 1.54 & 1.59 & 1.65 & 1.65 & - & - & - & - & - \\
\hline
\end{tabular}




\begin{tabular}{|c|c|c|c|c|c|c|c|c|c|c|}
\hline$p \mathrm{H}\left(\mathrm{H}_{2} \mathrm{O}\right)$ & 6.5 & 5.9 & 6.4 & 6.9 & 7.2 & 6.2 & 5.8 & 6.0 & 7.0 & 7 \\
\hline $\begin{array}{l}.4 \\
p \mathrm{H}\left(\mathrm{CaCl}_{2}\right)\end{array}$ & $\begin{array}{l}7.3 \\
5.5\end{array}$ & $\begin{array}{l}7.2 \\
4.8\end{array}$ & 5.4 & 6.1 & 6.2 & 5.5 & 5.4 & 5.9 & 6.1 & 6 \\
\hline .4 & 6.4 & 6.2 & & & & & & & & \\
\hline Org. matter $(\%)$ & 0.83 & 0.35 & 0.28 & 0.09 & 0.15 & 0.5 & 0.56 & 0.25 & 0.25 & 0 \\
\hline .34 & 0.19 & 0.15 & & & & & & & & \\
\hline Total N (\%) & 0.067 & 0.07 & 0.045 & 0.06 & 0.053 & 0.073 & 0.04 & 0.05 & 0.053 & 0 \\
\hline .053 & 0.034 & 0.028 & & & & & & & & \\
\hline $\begin{array}{l}\text { Available P } \\
(\mathrm{mg} / \mathrm{kg})\end{array}$ & 12.25 & 7.0 & 3.5 & 3.5 & 2.63 & 10.5 & 3.5 & 3.5 & 1.75 & 1 \\
\hline .75 & 1.75 & 1.75 & & & & & & & & \\
\hline \multirow[t]{2}{*}{ Total P (mg/kg) } & 341 & 171 & 512 & 853 & 256 & 1023 & 171 & 256 & 341 & 171 \\
\hline & 256 & 256 & & & & & & & & \\
\hline $\mathrm{Ca}(\mathrm{cmol} / \mathrm{kg})$ & 1.0 & 0.8 & 1.0 & 1.8 & 2.5 & 1.0 & 1.0 & 1.8 & 1.8 & 2 \\
\hline .5 & 2.5 & 2.5 & & & & & & & & \\
\hline $\mathrm{Mg}(\mathrm{cmol} / \mathrm{kg})$ & 0.18 & 0.12 & 0.183 & 0.37 & 0.37 & 0.17 & 0.183 & 0.37 & 0.43 & 0 \\
\hline .77 & 0.699 & 0.599 & & & & & & & & \\
\hline $\mathrm{K}(\mathrm{cmol} / \mathrm{kg})$ & 0.08 & 0.08 & 0.15 & 0.29 & 0.41 & 0.32 & 0.37 & 0.27 & 0.39 & 0 \\
\hline .48 & 0.75 & 0.43 & & & & & & & & \\
\hline $\mathrm{Na}(\mathrm{cmol} / \mathrm{kg})$ & 0.15 & 0.17 & 0.15 & 0.16 & 0.18 & 0.16 & 0.18 & 0.16 & 0.161 & 0 \\
\hline .2 & 0.181 & 0.196 & & & & & & & & \\
\hline $\mathrm{H}+\mathrm{Al}(\mathrm{cmol} / \mathrm{kg})$ & 0.1 & 0.2 & 0.1 & 0.1 & 0.1 & 0.1 & 0.2 & 0.2 & 0.1 & 0 \\
\hline .1 & 0.1 & 0.1 & & & & & & & & \\
\hline CEC (cmol/kg) & 3.2 & 2.6 & 3.4 & 4.7 & 6.2 & 2.8 & 3.6 & 5.2 & 5.6 & 7 \\
\hline .2 & 6.8 & 6.3 & & & & & & & & \\
\hline Base saturation (\%) & & & & & 58.9 & 48 & 50 & 49.7 & 54.9 & 60 \\
\hline .7 & 59.1 & & & & & & & & & \\
\hline
\end{tabular}

SL: Sandy loam; SC: Sandy clay; SCL: Sandy clay loam.

Vegetation

Vegetative cover for the grass surface and rice straw mulch surface plots during the first month (April) of rainfall events did not result in measurable runoff or sediment yield. As the rains stabilised, vegetative cover became more dominant. However, as the rainfall stabilised the monthly cumulative runoff difference between the grass, straw mulch and the bare plots began to increase until that of the bare plots was approximately 1.3 times that of grass plots and 3 times that of straw mulch plots (Table 2).

TABLE 2

Runoff depth (mm) for straw mulch, grass and bare plots

\begin{tabular}{lcrll}
\multicolumn{1}{c}{ Month } & $\begin{array}{l}\text { Straw mulch } \\
\text { (2001) }\end{array}$ & $\begin{array}{c}\text { Grass } \\
\text { (2003) }\end{array}$ & \multicolumn{2}{c}{ Bare } \\
& & & & 2001 \\
May & 1.5 & 8.1 & 0.8 & 23.4 \\
June & 73.6 & 35.2 & 228.84 & 105.1 \\
July & 12.7 & 13.4 & 43.76 & 31.7 \\
August & 16.7 & 117.6 & 53.84 & 11.8 \\
Sept & 2.8 & 77.2 & 2.77 & 138.8 \\
Mean & 21.5 & 50.3 & 65.5 & 62.2
\end{tabular}

Rainfall and runoff relation 
The rainfall amount increased from $152 \mathrm{~mm}$ in May 2001 to a maximum value of $433 \mathrm{~mm}$ in July. It then dropped to $248.7 \mathrm{~mm}$ and $148.7 \mathrm{~mm}$ in August and September, respectively. Similarly, in 2003, the rainfall depth increased from $114.6 \mathrm{~mm}$ in May and peaks at $416.2 \mathrm{~mm}$ in August (Fig. 2). The percentage runoff that resulted from the rainfall total was $8.3 \%, 17.9 \%$ and $23.8 \%$ for the straw mulch, grass and bare surface plots, respectively. The peak runoff did not correspond to the peak rainfall amount except for the grass plots (Fig. 2 and Table 2). This is expected because runoff depths do not depend sorely on rainfall amount and distribution. It is, rather, the rainfall intensity, topographic factor and soil texture, aggregate stability, shear strength and soil intake characteristics that are the main causative factors in runoff generation.

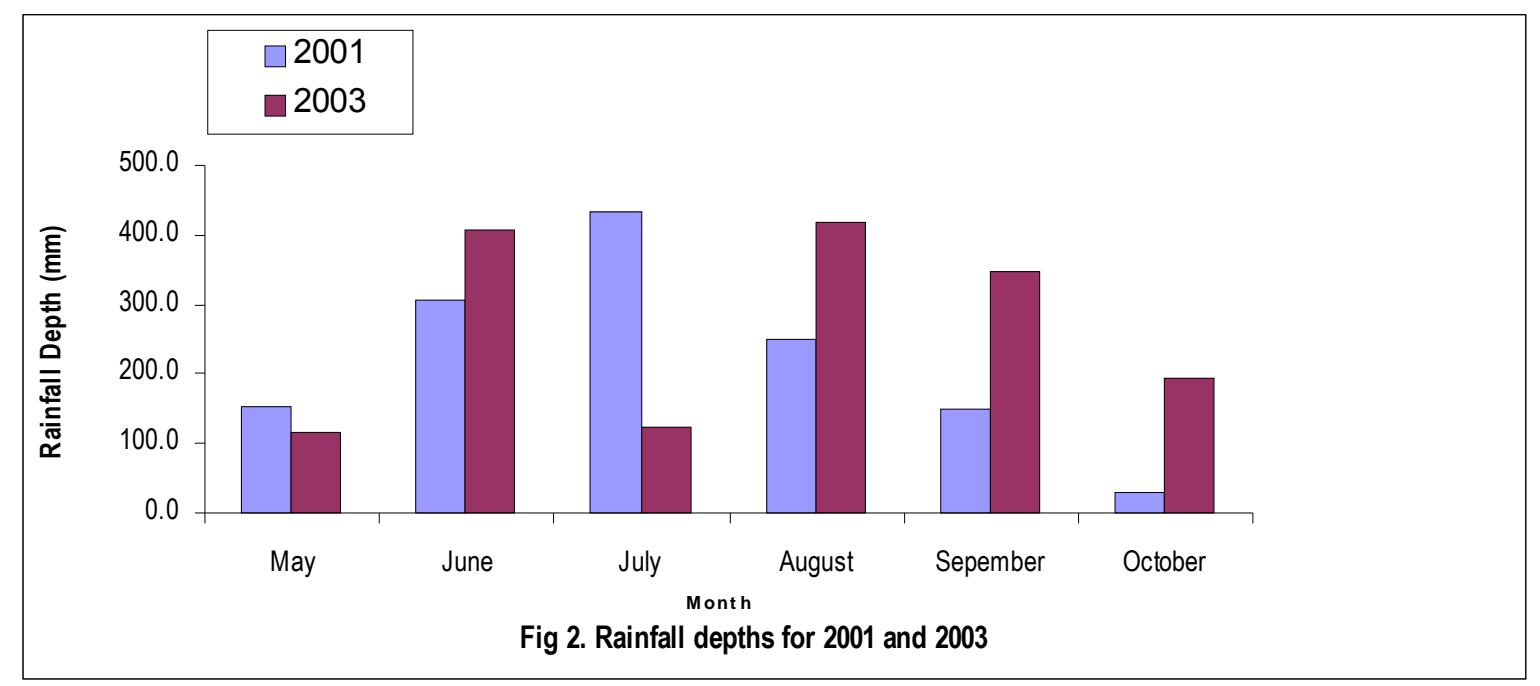

Month

Fig. 2. Rainfall depths for 2001 and 2003

\section{Sediment load from runoff}

The month of August of each year under consideration had the largest sediment yield with values of $0.56 \mathrm{t} / \mathrm{ha}$ and $1.8 \mathrm{t} / \mathrm{ha}$ from the straw mulch and grass surfaces, respectively (Fig. 3). Similarly, the maximum sediment yield occurred in August for bare plots amounting to $2.1 \mathrm{t} / \mathrm{ha}$ and $4.6 \mathrm{t} / \mathrm{ha}$ in 2001 and 2003, respectively. The cumulative sediment yield from the straw mulch and grass surfaces amounted to $1.12 \mathrm{t} / \mathrm{ha}$ and $2.92 \mathrm{t} / \mathrm{ha}$ resulting from $107.3 \mathrm{~mm}$ and $251.5 \mathrm{~mm}$ runoff. Similarly, the cumulative sediment yield from bare surfaces in 2001 and 2003 amounted to $7.49 \mathrm{t} / \mathrm{ha}$ and $8.9 \mathrm{t} / \mathrm{ha}$ resulting from $354.9 \mathrm{~mm}$ and $310.8 \mathrm{~mm}$ surface runoff, respectively. 


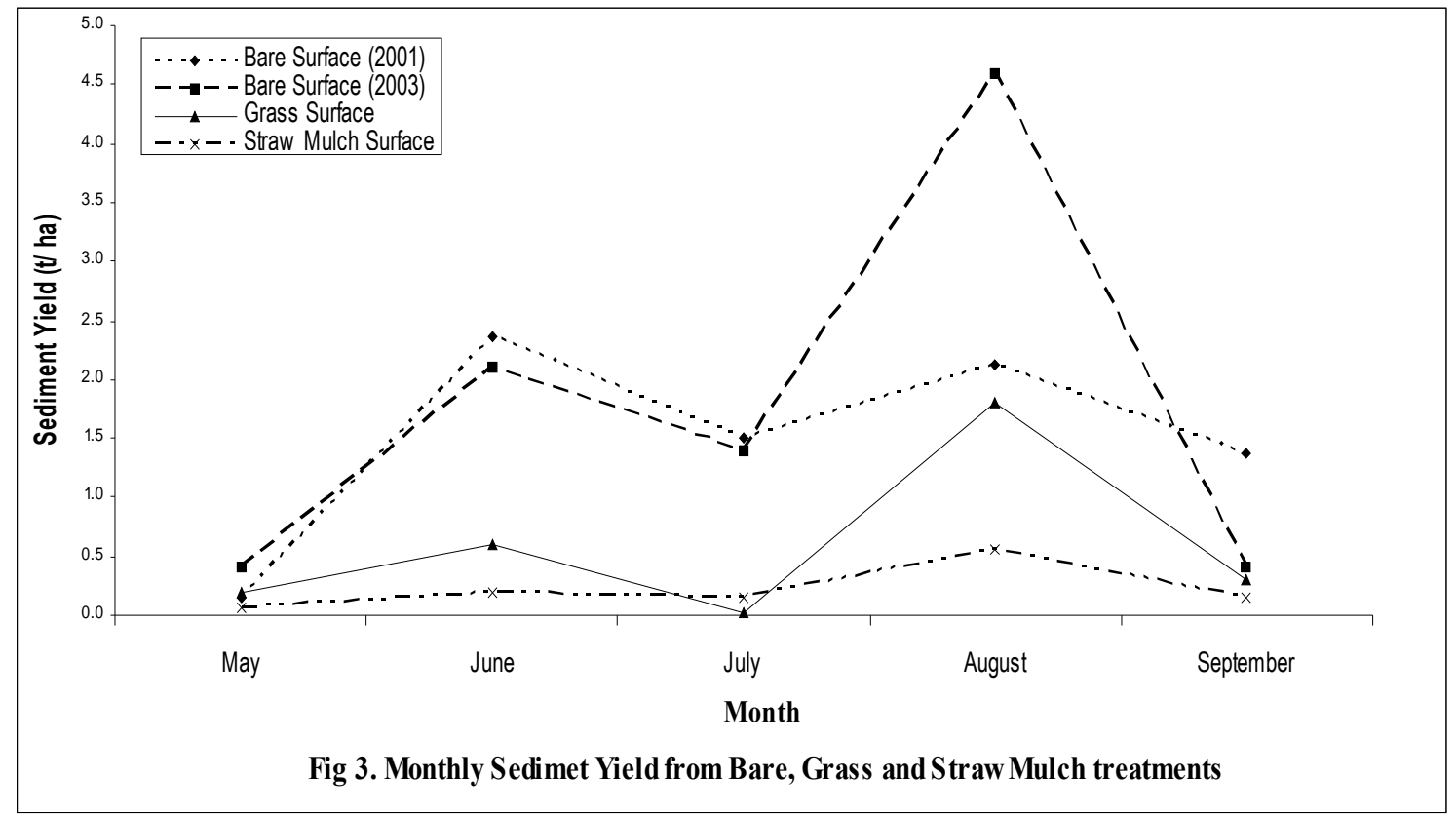

TABLE 3

Monthly Sediment Yield (t/ha) from Bare grass and straw mulch treatments (2001 \& 2003)

$\begin{array}{lllll}\text { Month } & \text { Grass } & \text { Surface } & \text { Straw } & \text { Mulch } \\ & & & & \\ \text { May } & 0.14 & 0.40 & 0.20 & 0.07 \\ \text { June } & 2.35 & 2.10 & 0.60 & 0.20 \\ \text { July } & 1.51 & 1.40 & 0.02 & 0.15 \\ \text { August } & 2.12 & 4.60 & 1.80 & 0.56 \\ \text { September } & 1.37 & 0.40 & 0.30 & 0.14\end{array}$

Bare Surface

$2001 \quad 2003 \quad 2001 \quad 2003$

The mean monthly sediment yield from bare plots was $1.49 \mathrm{t} / \mathrm{ha}$ and $1.78 \mathrm{t} / \mathrm{ha}$ in 2001 and 2003 , respectively. Hence, the 2 years mean monthly sediment yield then amounted to $1.64 \mathrm{t} / \mathrm{ha}$. The bare plots soil loss amounted to 2.8 and 7.5 times that of grass and straw mulch surfaces, respectively. The range of values of sediment yield from the bare plots for the study were in agreement with earlier studies carried out by Benik et al. (2003) in the southwest metropolitan area of St Paul, Minneapolis, Minnesota, U.S.A. In addition, these results agree with that of Benik et al. (2003) and Egharevba (2004) that stated that the sediment yield for any particular erosion control treatment generally increased with runoff depth.

Regression model

Considering the combined effect of natural rainfall amount (a), and the corresponding runoff depth (b), on the sediment load (y) generated, the following predictive equation was obtained:

$$
\mathrm{Y}=0.715-0.101 \mathrm{a}-0.173 \mathrm{~b}-0.227 \mathrm{ab} \quad\left(\mathrm{R}^{2}=0.14\right) .
$$

The expression (predictive equation) has a low coefficient of determination (14\%), indicating that additional factors (variables) are to be considered to improve on the equation. However, 
these preliminary regression coefficients were statistically significant at 0.40 confidence level and, therefore, remain as part of the mathematical model. The combined effect of the rainfall and runoff depths on the sediment yield was more than that of individual effect, as can be seen from the regression coefficients of the predictive (regression) model.

\section{Sediment size characterization}

Soil particles eroded during runoff were in the form of primary particles or aggregates and so tend to erode easily (Young, 1980). However, sandy soils are so permeable that very little rainfall accumulates to form runoff. Consequently, in the RUSLE sandy soils are considered to be less erodible. The result of the eroded particles size analysis was similar to the original soil texture (sandy loam) of the project site before commencement of the study. Once this accelerated erosion is effectively controlled, depletion of soil nutrient reserve will be curtailed, and decline in crop yield checked.

\section{Conclusion}

Rice straw mulch, grass and bare surface farm plots were evaluated under condition of southern Guinea savanna zone of Nigeria in the wet seasons of 2001 and 2003. The influence of these treatments on surface runoff and sediment yield was examined. From the study, the following conclusion can be dawn: (1) Observed runoff depth and sediment yield varied significantly by rainfall and by treatment. The mean monthly runoff from bare treatment was $65.5 \mathrm{~mm}$ and 62.2 $\mathrm{mm}$ in 2001 and 2003, respectively. (2) The peak sediment load under bare farm land environment was 2.35 t/ha (June) and 4.6 t/ha (August) in 2001 and 2003, respectively. (3) The predictive equation of sediment yield as a function of the rainfall amount and runoff depth under bare field condition was linear.

\section{References}

Alabi R. T. and Ibiyemi A. G. (2000). Rainfall in Nigeria and food crop production. In Agronomy in Nigeria. University of Ibadan, Ibadan, Nigeria. pp. 1-5.

Benik S. R., Wilson B. N., Biesboer D. D., Hensen B. and Stenlund D. (2003). Evaluation of erosion control products using natural rainfall events. J. Soil Wat. Conserv. 58(2): 83-85.

Egharevba N. A (2004). Evaluation of sediment yield from agricultural fields during natural rainfall events. J. Sustain. Trop. agric. Res. 11: 104-108.

FAO (1996). Control of water pollution from agriculture. Irrigation and Drainage paper 55. FAO, Rome. pp. 10-26.

Kaey R. W. (1959). An outline of Nigerian vegetation. Government printer, Lagos, Nigeria. 46 pp.

Laflen J. Flanagan D. and Engel B. (2004). Soil Erosion and Sediment Yield Prediction Accuracy Using WEPP. In Soil Erosion Prediction Technology for Improved Conservation Planning and Environmental Protection. J. Am. Wat. Resour. Ass. pp. 115-130.

Odofin A. J., Ezenwa M. I. S and Adeoye K. B. (2001). Effects of Tillage and residue mulch on soil moisture condition and maize performance on an Alfisol in the southern Guinea savanna. Paper presented at the 27th Annual Conference of Soil Science Society of Nigeria, Calabar, Nigeria.

Onochie E. F. A. (1977). Definition, classification and extent of Africa savannas. In Savannah afforestation in Africa. TF-RAF 95 (DEM), FAO, Rome, pp. 1-8.

Sanford W. W. and Isicheri A. O. (1980). West Africa savanna. In West African Ecology. (G..Lawson, ed.). John Wiley. pp. 1-5.

Soil and Water Conservation Society (1993). RUSLE users guide. Soil and Water Conservation Society, Ankeny, USA. 164. pp.

Soil Survey Staff (1990). Keys to soil taxonomy. SMSS Technical Monograph No.6. Blacksburg, Virginia.

Webster C. C. and Wilson P. N. (1980). Agriculture in the trophics, 2nd edn. Longman Group Ltd. New York. pp. 103-140.

White S. (1988). Sediment yield and availability for two reservoir drainage basins in Central Luzono, Philippines. In Sediment Budget. (M. P. Bordas and D. E. Walling, ed.). IAHS Publ. No. 174. Int. Assoc. Hydrol. Sci, Wallingford, U.K.

Young R. A. (1980). Characteristics of eroded sediment. Trans. Am. Soc. agric. Engrs. (ASAE) 23: 1146. 